\title{
REPORT ON FERTILITY AFTER VIRILIZATION WITH ANDROGENS IN A MAN WITH MINUTE TESTICLES AND EUNUCHOIDISM
}

\author{
G. L. FOSS \\ 3 Litfield Place, Clifton Down, Bristol 8
}

(Received 19th November 1963)

\begin{abstract}
Summary. The case of a male eunuchoid aged 32 years is described. Of $46 \mathrm{XY}$ karyotype, his testes showed complete absence of spermatogenesis. Small immature hyalinized tubules were lined only with Sertoli cells, and Leydig cells were difficult to find. After treatment for 8 years with androgens, at first by injection and for the rest of the time by mouth, he developed full virilization and later fertility. His wife became pregnant and gave birth to a child with cyanotic congenital heart disease.
\end{abstract}

\section{CASE REPORT}

The prognosis of fertility in a patient presenting in middle life with eunuchoidism is generally assumed to be bleak. During the last 28 years I would without hesitation have advised such a patient that, by having continuous treatment with androgens, his virilization and normal sexual function could be guaranteed and that he could lead a normal married life, but unfortunately he would be sterile.

It was then that a eunuchoid, whom I had so transformed and who was happily married, informed me that his wife was expecting a baby.

This man, a van driver, was first seen at the age of 30 years. A normal child with no history of mumps, he did not develop puberty, and was turned down for National Service at 19 years. He started courting at 30 years, but was worried about the small size of his genitalia, and went to his doctor. Erection was very small and occurred infrequently. He had never shaved and his voice had not broken. He was engaged, and hoped to marry. He had one brother of 32 years and a sister, both married with children.

On examination in April 1952 he had a tall, slim eunuchoid figure (Pl. 1, Fig. 1); height $68 \frac{1}{4}$ in. $(173.4 \mathrm{~cm})$, span $75 \frac{1}{2}$ in. $(190.5 \mathrm{~cm})$, upper measurement (crown to symphysis pubis) $32 \frac{1}{2}$ in. $(82 \cdot 6 \mathrm{~cm})$, lower measurement $35 \frac{3}{4}$ in. $(90.8 \mathrm{~cm})$, weight 9 stone 5 pounds $(60 \mathrm{~kg})$. His muscles were soft and undeveloped, and there was slight dorsal kyphosis. The skin of his face was smooth and without hair. There was no hair in the axillae, but a little around the base of the small penis. The scrotum was small but slightly rugose (Pl. 1, Fig. 4). The flaccid extended length of the penis was $5.4 \mathrm{~cm}$ and there were two infantile-sized testes in the scrotum. His nipples were immature, and there was no gynaecomastia. His voice was like that of a prepubertal boy. 


\section{INVESTIGATIONS}

The sella turcica was on the small side of normal. The skeletal age was 15 years, and the iliac crest epiphyses were present but not fully developed.

The electrocardiograph showed a normal pattern. ${ }^{131} \mathrm{I}$ uptake at $4 \mathrm{hr}$ was $23 \%$ of the dose given, and protein-bound iodine at $48 \mathrm{hr}$ was $0.02 \%$ of the dose per litre: these are normal figures. 17-Oxosteroid excretion rate was $3 \mathrm{mg} / 24 \mathrm{hr}$. Gonadotrophin excretion, assayed by the mouse uterus test: $7.8 \mathrm{HMG}$ units/24 hr, within the normal range for a patient of this age. Chromosome analysis showed a normal $46 \mathrm{XY}$ karyotype. He was unable to produce any ejaculate.

The right testis was removed entire and measured $1.5 \times 1.0 \times 0.7 \mathrm{~cm}$. It was fixed in Bouin's solution, and sections were stained by haematoxylin and eosin and also with van Gieson stain. All the sections were photographed at a

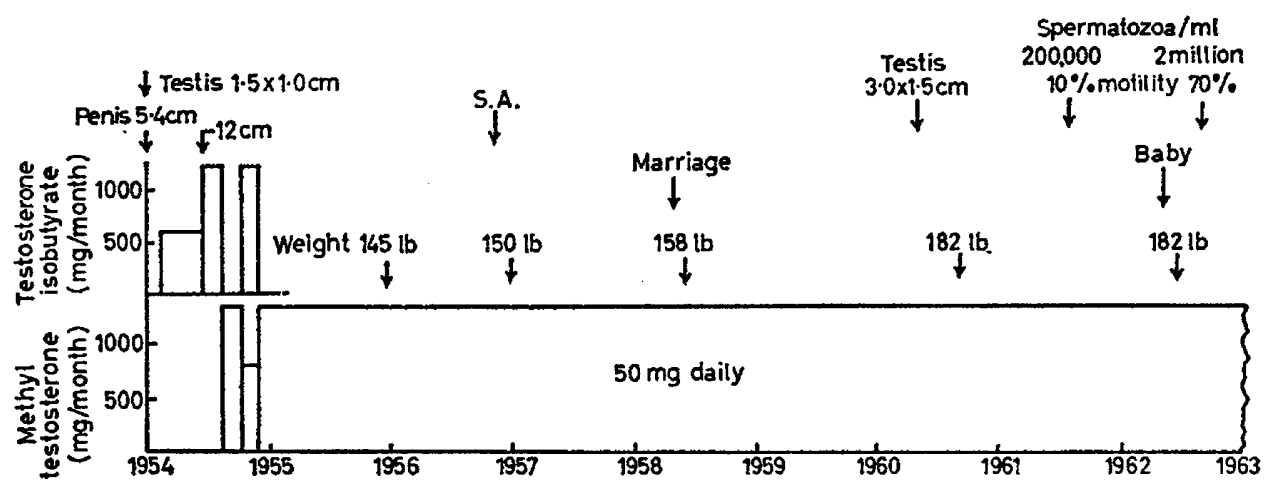

TEXT-FIG. 1. Diagram of androgen treatment of patient A. K. aged 32 years and weighing $131 \mathrm{lb}$ at start of treatment.

magnification of 200 , with sections from a normal male of the same age for comparison. The preparations showed that the tubules were small and immature, and were lined mainly by Sertoli cells. Some were hyalinized and separated by oedematous stroma (Pl. 2, Fig. 5), while others were tightly packed without hyalinization (Pl. 2, Fig. 6). There was no evidence of spermatogenesis, interstitial cells were very scanty, and there was no evidence of a chronic inflammatory process. Elastic tissue was scanty in the tunica propria as compared with that of a normal control of the same age (Pl. 2, Figs. 7 and 8 ).

This patient failed to follow up, and was eventually seen 2 years later, when his general appearance and epiphyseal maturation were unchanged.

\section{TREATMENT}

This consisted of injections of testosterone isobutyrate, $300 \mathrm{mg}$ once a fortnight at first and then once a week. After 8 months, continuous treatment with methyl testosterone, $50 \mathrm{mg} /$ day, was substituted and is still continued (Textfig. 1). 


\section{PLATE 1}

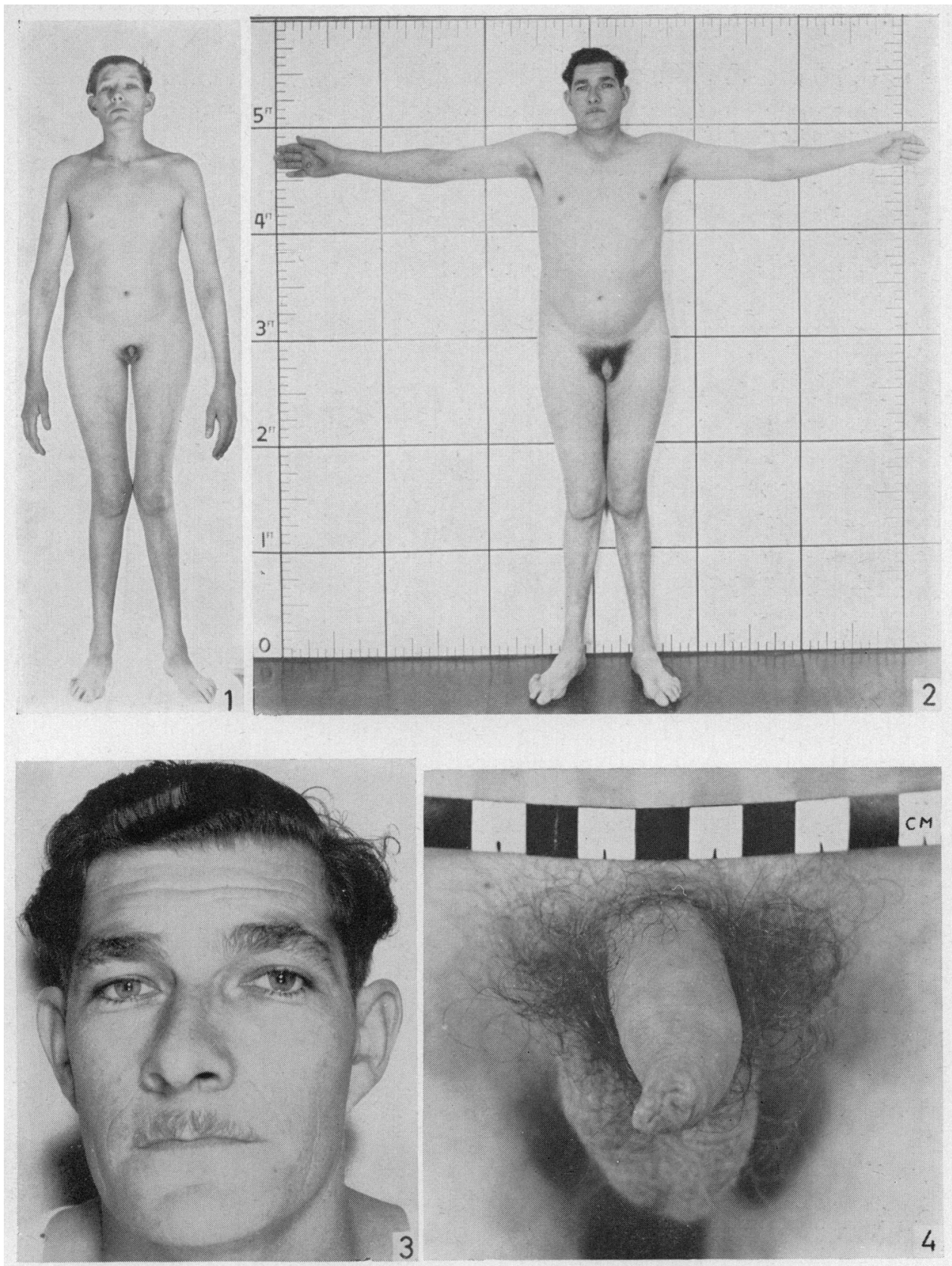

FIG. 1. Eunuchoid aged 30 years (1952).

FIGs. 2 and 3. Eunuchoid after 6 years' treatment with androgens FIG. 4. Genitalia (1952).

(Facing p. 374) 
PLATE 2

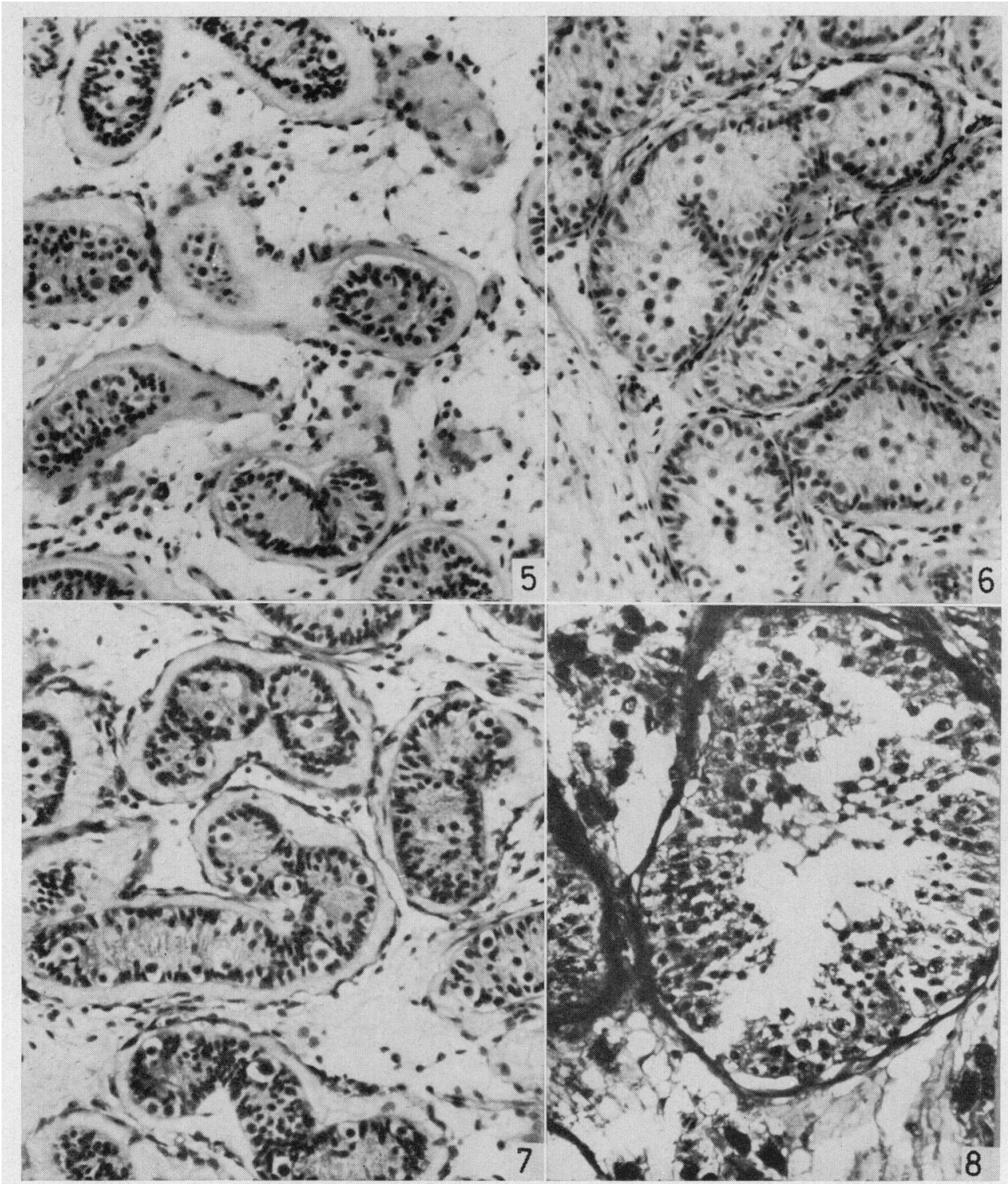

FIG. 5. Eunuchoid testis. Atrophic tubules with hyalinized tunica in an oedematous stroma. Haematoxylin and eosin. $\times 200$.

Fig. 6. Eunuchoid testis (another field). Tightly-packed immature tubules without spermatogenesis, hyperplasia of Sertoli cclls. Haematoxylin and eosin. $\times 200$.

FIG. 7. Eunuchoid testis. Absence of elastic tissue in tunica propria, cf. Fig. 8. Van Giesen. $\times 200$.

Fig. 8. Normal testis at age 30 years. Van Giesen. $\times 200$. 
PROGRESS

Virilization was rapid, and after 5 months the flaccid extended length of his penis was $12 \mathrm{~cm}$ and he was able to masturbate with emission, and shaved three times per week. There was complete azoospermia.

After $2 \frac{1}{2}$ years seminal analysis showed six degenerate non-motile spermatozoa. 17-Oxosteroids were excreted at the rate of $11 \mathrm{mg} / 24 \mathrm{hr}$ while taking methyl testosterone, and 17-hydroxycorticosteroids at $17 \cdot 7 \mathrm{mg} / 24 \mathrm{hr}$.

After 6 years he married, and frequent and satisfactory coitus occurred. At this time his left testis measured $3 \times 1.5 \mathrm{~cm}$. Epiphyseal maturation was still incomplete and the iliac crest epiphysis was not completely fused.

After $7 \frac{1}{2}$ years' continuous treatment he reported that his wife was pregnant, and a seminal analysis surprisingly showed 200,000 spermatozoa $/ \mathrm{ml}$, with $10 \%$ motility.

The virilizing and anabolic effects of prolonged androgen treatment are well illustrated in Pl. 1, Fig. 2 (1960) when he was well muscled and hirsute and grew a moustache (PI. 1, Fig. 3).

TABLE 1

EXCRETION OF 17-OXOSTEROIDS AND 17-HYDROXYCORTICOSTEROIDS

\begin{tabular}{l|c|c}
\hline & $\begin{array}{c}17-\text { Oxosteroids } \\
(\mathrm{mg} / 24 \mathrm{hr})\end{array}$ & $\begin{array}{c}17-\text { Hydroxycorticosteroids } \\
(\mathrm{mg} / 24 \mathrm{hr})\end{array}$ \\
\hline Before metopirone & $9 \cdot 5$ & $14 \cdot 6$ \\
After 24 hr & $6 \cdot 5$ & $13 \cdot 2$ \\
After $48 \mathrm{hr}$ & $7 \cdot 7$ & $16 \cdot 3$ \\
\hline
\end{tabular}

Owing to pelvic disproportion, as his wife was a cripple, the baby was born (in a Bath hospital) by Caesarean section. It had cyanotic congenital heart disease and died shortly after. Unfortunately no blood was taken from the child for typing, as both mother and father had been fully typed and showed Group A Rhesus negative blood. The genotype of the father was $\mathrm{cD}^{\mathrm{u}} \mathrm{E} / \mathrm{cde}$ and of the mother cde/cde.

Further seminal analyses after the birth of this child showed 2 million spermatozoa/ml with $70 \%$ active motility, and 3.2 million spermatozoa $/ \mathrm{ml}$ with $80 \%$ active progressive movement, and stained films showed that most of the spermatozoa were normal.

After withdrawal of methyl testosterone for a month a metopirone test was carried out. Metopirone, $250 \mathrm{mg}$, was given by mouth every $2 \mathrm{hr}$ for 2 days, but there was no evidence of any response (Table 1).

A dexamethasone adrenal suppression test was also carried out using $3 \mathrm{mg}$ daily for 4 days. After withdrawal of methyl testosterone for 2 months 17-oxosteroids were excreted at the rate of $4.7 \mathrm{mg} / 24 \mathrm{hr}$, and after 4 days of dexamethasone the rate fell to $3.2 \mathrm{mg} / 24 \mathrm{hr}$.

As a result of stopping methyl testosterone erection was inadequate for 
satisfactory coitus. At no time during this prolonged treatment with methyl testosterone was there any ill effect or suggestion of cholostatic jaundice (Foss \& Simpson, 1959).

\section{DISCUSSION}

There was no evidence that this patient had any deficiency of thyrotrophic, adrenocorticotrophic or growth hormones, and no evidence of an intra- or extra-sellar tumour. He is probably a case of hypogonadotrophic hypogonadism (Heller \& Nelson, 1948).

The testicular tubules were small and immature, and were lined mainly with Sertoli cells with no evidence of spermatogenesis. Some of them were hyalinized, a condition which Howard, Sniffen, Simmon \& Albright (1950) considered to be due to a degenerative lesion after failure of $\mathrm{FSH}$, as may be seen in patients with pituitary tumours, or after oestrogen treatment, but it also occurs in Klinefelter's syndrome in which there is a high titre of FSH.

This patient had almost complete absence of Leydig cells. Elastic tissue was also deficient in the tunica propria. It is known that elastic fibres do not appear normally until puberty, and De la Balze, Bur, Scarpa-Smith \& Irazu (1954) found that in cases of eunuchoidism with low FSH the elastic fibres were absent even in the sclero-hyalinized tubules in the older age groups.

According to De la Balze, Arrillaga, Irazu \& Mancini (1952) the seminiferous tubule is a secondary sex characteristic and is dependent on androgens for its development at puberty.

In the experimental animal spermatogonia persist after hypophysectomy and appear to be independent of both pituitary and testicular hormones; either testosterone or interstitial cell stimulating hormone will maintain spermatogenesis if injected within a few days after hypophysectomy. Under certain conditions androgens can re-initiate as well as maintain spermatogenesis in the hypophysectomized rat (Dorfman \& Shipley, 1956). Wood \& Simpson (1961) state that in the hypophysectomized male rat ICSH is the primary anterior pituitary hormone responsible for maintenance of seminiferous epithelium as well as Leydig cell tissue. After regression of the testis in the hypophysectomized rat it required not only ICSH but also FSH to induce tubular differentiation and sometimes spermatogenesis, so that both hormones are probably essential for normal spermatogenesis.

Heller \& Nelson (1948) reported a case of hypogonadotrophic hypogonadism aged 26 years in which the infantile testes developed Leydig cells after injections of chorionic gonadotrophin, and later spermatogenesis when FSH was added.

There have been several reports in the literature of cases of hypogonadism which, after treatment with androgens by mouth, injection or implantation, have developed spermatogenesis and fertility. The five cases reported by Hurxthal, Bruns \& Musulin (1949) are, however, incompletely documented; three were eunuchoids, but the others may have been 'fertile eunuchs', as described by McCullagh, Beck \& Schaffenburg (1953) and by Pasqualini (1953). These are not necessarily of eunuchoid build; they have moderate or slight pubic hair and a small penis, but their testes and tubules are of normal size and show some spermatogenesis. FSH is normal, and ICSH is low or normal. 
Kinsell (1947) described a 24-year-old dwarf with infantilism. He had normal-sized, prepubertal, thin-walled tubules and no spermatogenesis, but after 5 months' treatment with implants of testosterone he produced 18 million spermatozoa $/ \mathrm{ml}$ of ejaculate. Perlman (1949) reported a eunuchoid male of 31 years with testes smaller than normal, a small penis, no ejaculate. He had had mumps at 10 years, but no biopsy was obtained, and after treatment with methyl testosterone and gonadotrophin he produced 12 million spermatozoa $/ \mathrm{ml}$ of ejaculate.

G. I. M. Swyer (personal communication) told me recently (1963) of a case similar to mine with eunuchoidism, who after implants of testosterone became fertile with a sperm density of 4 million/ $/ \mathrm{ml}$, and whose wife gave birth to twins, conceived but aborted a second pair, and was at the time of writing pregnant for a third time.

In the case described here the emphasis was placed on the rapid and complete development of virilization with androgens to enable him to marry. It would have been interesting firstly to have tried treatment with gonadotrophin, and secondly to have obtained another biopsy, but the latter was felt to be unjustified.

One must conclude that the prolonged treatment of some cases of chromatinnegative hypogonadism with androgens may ultimately be followed by testicular tubular development and spermatogenesis, and that a prognosis of sterility in such a case should therefore be made with reservation.

\section{ACKNOWLEDGMENTS}

I am indebted to Drs A. L. Taylor and N. J. Brown for sections and histological reports, and to the latter for microphotographs; to $\mathrm{Dr} J$. A. Loraine for the gonadotrophin assay, to Dr R. C. Tudway for arranging the ${ }^{131} \mathrm{I}$ uptake test, to Dr G. K. McGowan for the steroid assays, to Dr G. H. Tovey for the blood grouping, and to Dr F. J. W. Lewis for the chromosome analysis. The clinical photographs were supplied by the Department of Medical Photography. The testosterone isobutyrate was kindly given by Dr A. K. Pitman of Messrs Ciba Ltd.

\section{REFERENCES}

de la Balze, F. A., Arrillaga, F. C., Irazu, J. \& Mancini, R. E. (1952) Klinefelter syndrome; a study of 5 cases. Histophysiologic basis for a pathogenic interpretation. 7 . clin. Endocrin. 12, 1426.

de la Balze, F. A., Bur, G. E., Scarpa-Smith, F. \& Irazu, J. (1954) Elastic fibres in the tunica propria of normal and pathologic human testes. 7 . clin. Endocrin. 14, 626.

Dorfman, R. I. \& Shipley, R. A. (1956) Androgens. Chapman \& Hall, London.

Foss, G. L. \& Simpson, S. L. (1959) Oral methyltestosterone and jaundice. Brit. med. 7. i, 259.

Heller, C. G. \& Nelson, W. O. (1948) Classification of male hypogonadism and a discussion of the pathologic physiology, diagnosis and treatment. 7. clin. Endocrin. 8, 345.

Howard, R. P., Sniffen, R. G., Simmon, F. A. \& Albright, F. (1950) Testicular deficiency; a clinical and pathologic study. J. clin. Endocrin. 10, 121.

Hurxthal, L. M., Bruns, H. J. \& Musulin, N. (1949) Development of spermatogenesis in hypogonadism. F. clin. Endocrin. 9, 1245.

Kinsell, L. W. (1947) Spermatogenesis in a panhypopituitary eunuchoid as the result of testosterone therapy. 7. clin. Endocrin. 7, 781.

McCullagh, E. P., Beck, J. G. \& Schaffenburg, C. A. (1953) A syndrome of eunuchoidism with spermatogenesis, normal FSH, and low or normal ICSH ('Fertile eunuchs'). J. clin. Endocrin. 13, 489 . 
Pasqualini, R. Q. (1953) Hypoandrogenic syndrome with normal spermatogenesis. F. clin. Endocrin. 13, 128.

Perlman, R. M. (1949) Spermatogenesis following administration of androgen and gonadotrophin in a case of eunuchoidism. 7. clin. Endocrin. 9, 163.

Wood, M. C. \& Simpson, M. E. (1961) Pituitary control of the testis of the hypophysectomised rat. Endocrinology, 69, 91 . 